\title{
Impact of the Functional VNTR Variants of the Interleukin-1 Receptor Antagonist and Interleukin-4 Genes on Oral Squamous Cell Carcinoma
}

\author{
Interlökin-1 Reseptörü Antagonisti ve Interlökin-4 Gen Fonksiyonel VNTR \\ Varyantlarının Oral Skuamöz Hücreli Karsinoma Etkisi
}

\author{
(1) Özge Gümüşay1, (1) Ayșe Feyda Nursal2, (1) Serbülent Yiğit³, (1) Akın Tekcan4, (1) Tuba Öz³ \\ ${ }^{1}$ Tokat Gaziosmanpașa University, Faculty of Medicine, Department of Medical Oncology, Tokat, Turkey \\ ${ }^{2}$ T.C. Hitit University, Faculty of Medicine, Department of Medical Genetics, Çorum, Turkey \\ ${ }^{3}$ Tokat Gaziosmanpașa University, Faculty of Medicine, Department of Medical Biology, Tokat, Turkey \\ ${ }^{4}$ Kırșehir Ahi Evran University, Faculty of Medicine, Department of Medical Biology, Kırşehir, Turkey
}

\begin{abstract}
Introduction: It has been shown that the host immune response and chronic inflammation could play a role as important risk factors for cancer. Oral squamous cell carcinoma (OSCC) is a common cancer worldwide. In this study, we aimed to evaluate the impact of interleukin-1 receptor antagonist (IL-1RA) and IL-4 variable number tandem repeat (VNTR) polymorphisms on OSCC susceptibility in a Turkish population.
\end{abstract}

Methods: Study subjects comprised of 36 OSCC patients and 100 healthy controls. Genotyping of the IL-1RA VNTR (rs2234663) and IL-4 VNTR (rs79071878) polymorphisms were analyzed by polymerase chain reaction.

Results: The frequency of IL-1RA VNTR 1/2+2/2 genotypes increased in the patients than healthy controls while IL-1RA VNTR 1/1 genotype was higher in the control group than in the patients $(p=0.002)$. The subjects carrying IL-1RA VNTR $1 / 2+2 / 2$ genotypes showed a 12.011-fold increased risk of susceptibility to OSCC. IL-1RA VNTR allele 1 was higher in the control group than the patient group while IL-1RA VNTR allele 2 was higher in the patient group than the control group (respectively, $p=0.000$, $p=0.000$ ). The subjects carrying IL-1RA VNTR allele 2 showed a 2.609-fold increased risk of susceptibility to OSCC. The IL-4 VNTR P1/P1 and P1/P2 genotype frequencies were higher in the patient group compared to the control group $(p=0.039)$. IL-4 VNTR P1 allele was higher in the patients compared to the controls $(p=0.030)$.

Conclusion: The significant association between the functional VNTR polymorphisms of IL-1RA/IL-4 genes and OSCC suspectibility in a Turkish population confirmed a role of altered inflammatory process in OSCC pathogenesis.

Keywords: Oral squamous cell carcinoma, IL-1RA, IL-4, VNTR, polymorphism

\section{öz}

Amaç: Konakçı immün cevabının ve kronik enflamasyonun kanser için önemli risk faktörleri olarak rol oynadığı gösterilmiş̦ir. Oral skuamöz hücreli kanser (OSHK) tüm dünyada yaygın bir kanser türüdür. Bu çalışmada Türk toplumunda interlökin-1 reseptörü antagonisti (IL-1RA) ve IL-4 değişken sayılı ardışık tekrar (VNTR) polimorfizminin OSHK yatkınlığına olan etkisini incelemeyi amaçladık.

Yöntemler: Çalıșma grubu 36 OSHK hastası ve 100 sağlıklı kontrolden oluşmaktadır. IL-1RA VNTR (rs2234663) ve IL-4 VNTR (rs79071878) polimorfizmlerinin genotiplemesi polimeraz zincirleme tepkimesi ile analiz edildi.

Bulgular: IL-1RA VNTR $1 / 1$ genotipi kontrol grubunda hastalardan daha fazla iken IL-1RA VNTR 1/2+2/2 genotipleri hastalarda sağlıklı kontrollere göre artmıștı $(p=0,002)$. IL-1RA VNTR 1/2+2/2 genotiplerini tașıyan kișiler OSHK'ye yatkınlık yönünden 12,011 kat fazla risk gösterdiler. IL-1RA VNTR allel 2 hasta grubunda kontrol grubundan daha fazla iken IL-1RA VNTR allel 1 kontrol grubunda hasta grubundan daha fazlaydı (sırasıyla, $p=0,000, p=0,000$ ). IL-1RA VNTR allel 2 taşıyan kişiler OSHK'ye yatkınlık yönünden 2,609 kat fazla risk gösterdiler. IL-4 VNTR P1/P1 ve P1/P2 genotip sıkığı hasta grubunda kontrol grubuna göre daha fazlaydı $(p=0,039)$. IL-4 VNTR P1 alleli hastalarda kontrollere göre daha yüksekti $(p=0,030)$.

Sonuç: Türk popülasyonundaki IL-1RA/IL-4 VNTR polimorfizmleri ve OSHK yatkınlığı arasındaki önemli ilişki OSHK etiyopatogenezinde değişen enflamatuvar işlevlerin rolü olduğunu doğrulamıştır.

Anahtar Kelimeler: Oral skuamöz hücreli karsinom, IL-1RA, IL4, VNTR, polimorfizm
Address for Correspondence/Yazıșma Adresi: Ayșe Feyda Nursal MD, T.C. Hitit University, Faculty of Medicine, Department of Medical Genetics, Corum, Turkey

Phone: +90 3642221100 E-mail: feyda.nursal@gmail.com ORCID ID: orcid.org/0000-0001-7639-1122

Cite this article as/Atıf: Gümüşay Ö, Nursal AF, Yiğit S, Tekcan A, Öz T. Impact of the Functional VNTR Variants of the IL-1RA and IL-4 Genes on Oral Squamous Cell Carcinoma. İstanbul Med J 2019; 20(3): 202-7.
Received/Geliș Tarihi: 20.09.2018 Accepted/Kabul Tarihi: 31.12.2018

(c) Copyright 2019 by the Istanbul Training and Research Hospital/Istanbul Medical Journal published by Galenos Publishing House.

(C) Telif Hakkı 2019 istanbul Ĕgitim ve Araștırma Hastanesi/Istanbul Tıp Dergisi, Galenos Yayınevi tarafından basılmıștır. 
Gümüşay ve ark. IL-1RA/IL-4 Gene Variants in OSCC

\section{Introduction}

Oral cancer is among the most frequent cancers in the world. Its pathogenesis remains unclear. Oral squamous cell carcinoma (OSCC) originates from the squamous cells that cover the mouth mucosa and is a common type of oral cancer, responsible for more than $90 \%$ of cases (1). Risk factors for OSCC include smoking, alcohol use, and human papilloma virus infections (2), however, molecular mechanisms associated with OSCC are still being under research, and genetic predisposition is gaining interest of the scientists.

In recent years, the role of leucocytes and their relevant cytokines in inflammatory mechanisms and malignant transformation has been well investigated and documented by many studies. The interleukin-1 receptor antagonist (IL-1RA) is a significant innate cytokine that hinders IL-1 activity by binding to the IL-1 receptors without causing any signal transmission (3). The gene encoding IL-1RA (IL-1RA, also called IL-1RN) is found in the chromosome $2 q 14$ and there is an identified variant occurring as a result of variable numbers of an 86-bp tandem repeat (VNTR) (rs2234663) in intron 2 (4). This variant causes the presence of five alleles, each linked with a distinct to a distinct number of repeats. The allele 2 of IL-1RA VNTR variant was found to be related to elevated production of the IL-1 $\beta$ in vitro (5).

The human IL-4 is a cytokine synthesized in CD4+Th2 cells, basophils and mast cells, which has a role in the modulation of the humoral immune response (6). IL-4 also interferes with the secretion of the pro-inflammatory cytokines tumor necrosis factor alpha (TNF- $\alpha$ ), IL- 6 and IL-1. It can also stimulate the production and secretion of anti-inflammatory factors including IL-1RA (7). The gene encoding IL-4 is found in the chromosome $5 q 31.1$ and there is a $70 \mathrm{bp}$ VNTR (rs79071878) variant in its third intron that might alter the expression of IL-4 gene; with the P1 allele increasing IL-4 expression compared to the P2 allele (7). Numerous genetic susceptibility research has been done to examine the relations between the IL1-RA and IL-4 VNTR variants and different types of cancers, but results were inconsistent. Considering the importance of IL-1RA and IL-4 cytokines in inflammatory disorders, in this study, our purpose was to evaluate the possible association between IL-1RA/IL-4 VNTR variants and an increased risk of potential OSCC in a Turkish population.

\section{Methods}

\section{Study population}

The study included 36 Turkish patients with histologic diagnosed OSCC, who were recruited at the Department of Medical Oncology, Gaziosmanpasa University, Faculty of Medicine, Turkey. One hundred healthy participants with no medical history of cancer were enrolled in the control group. Patients who had oral precancerous diseases including oral submucous fibrosis, leukoplakia, erythroplakia, and verrucous hyperplasia were excluded from the control group. All subjects had come from the same geographic area. Tumor degree was assessed by a pathologist using the AJCC classification. Informed consent was obtained from all participants before they were enrolled in this study. The study was carried out in compliance with the Declaration of Helsinki and was approved by the Hitit University Faculty of Medicine Regional Ethical Committee (2017/200).

\section{Genotyping}

For all participants, peripheral blood was collected into tubes with EDTA as an anticoagulant. Genomic DNA was extracted from the samples by the DNA extraction kit (Sigma-Aldrich, St. Louis, MI, USA) and was kept at $-20{ }^{\circ} \mathrm{C}$ until investigation. The VNTR polymorphisms in IL-1RA and $I L-4$ genes were examined by the polymerase chain reaction (PCR) method described previously, respectively $(4,8)$. The identification of IL-1RA VNTR polymorphism was done by the PCR technique using the forward 5'-CTC AGC AAC ACT CCT AT-3' and reverse 5'-TTC CAC CAC ATG GAA C-3' primers following these conditions: first, an initial denaturalization at $94{ }^{\circ} \mathrm{C}$ for 4 minutes; second, 30 cycles at $94{ }^{\circ} \mathrm{C}$, $51{ }^{\circ} \mathrm{C}$ for 30 seconds, and $72{ }^{\circ} \mathrm{C}$ for 45 seconds at each temperature; and third, final extension at $72{ }^{\circ} \mathrm{C}$ for 5 minutes. PCR products were separated by electrophoresis within a $3 \%$ agarose gel and visualized by ethidium bromide staining. Five different alleles of IL-1RA were identified as follows: allele 1, four repeats (410 bp); allele 2, two repeats (240 bp); allele 3, five repeats (500 bp); allele 4, three repeats (325 bp), and allele 5 , six repeats (595 bp).

For IL-4, amplification was done using the forward 5'AGG CTG AAA GGG GGA AAG C-3' and reverse 5'-CTG TTC ACC TCA ACT GCT CC-3' primers, with initial denaturation at $95^{\circ} \mathrm{C}$ for 5 minutes, 30 cycles of denaturation at $94{ }^{\circ} \mathrm{C}$ for 30 seconds, annealing at $58{ }^{\circ} \mathrm{C}$ for 45 seconds, extension at $72{ }^{\circ} \mathrm{C}$ for 1 minutes and final extension at $72{ }^{\circ} \mathrm{C}$ for 10 minutes. PCR was done in a $25 \mu \mathrm{l}$ reaction mixture containing $50 \mathrm{ng}$ DNA, $0.8 \mu \mathrm{M}$ of each primer, $200 \mu \mathrm{M}$ of each dNTP, $2.5 \mathrm{mM} \mathrm{MgCl}, 1.5$ units Taq polymerase, $2.5 \mu \mathrm{l} 10 \times \mathrm{KCl}$ buffer. The resultant PCR products were examined by gel electrophoresis. The PCR products were of $183 \mathrm{bp}$ for the P1 allele and $253 \mathrm{bp}$ for the $\mathrm{P} 2$ allele.

\section{Statistical Analysis}

The SPSS software version 20.0 (Chicago, IL, USA) and OpenEpi ver. 3.01 was used for all statistical analyses. Continuous data were presented as mean \pm standard deviation (SD) and minmax. Chi-square test was used to determine the significance of differences in allele frequency and genotype distributions between the groups. The odds ratio (OR) and $95 \%$ confidence intervals (Cls) were calculated. A p value of less than 0.05 was considered statistically significant.

\section{Results}

This study included 36 OSCC patients (22 males and 14 females; mean age \pm SD, 63.94 \pm 13.96 years) and 100 healthy unrelated subjects as the control group (65 males and 35 females; mean age \pm SD, 57.31 \pm 11.85 years). The baseline demographic and clinical features of the studied cases were summarized in Table 1.

\section{IL-1RA genotyping}

The allelic and genotype frequencies of the IL-1RA VNTR polymorphism among the patients with OSCC and the healthy control subjects are summarized in Table 2. The significant difference between patients and controls was observed for both genotype and allele frequencies of IL-1RA VNTR polymorphism. In our population, we did not found individuals carrying the following genotypes: 1/4, 1/5, 2/3, 2/4, 2/5, 3/4, 3/5, 4/4, 4/5 and $5 / 5$. The genotypic frequencies of the IL-1RA VNTR polymorphism 
Table 1. Baseline clinical and demographics features of the patients with OSCC

\begin{tabular}{|c|c|c|}
\hline Characteristics & Controls $(n=100)$ & Patients ( $n=36$ ) \\
\hline Gender, male/female, n (\%) & $65 / 35(65.0 / 35.0)$ & $22 / 14(61.1 / 38.9)$ \\
\hline Age, mean $\pm S D$, years & $57.31 \pm 11.85$ & $63.94 \pm 13.96$ \\
\hline Smoking & - & - \\
\hline Yes, n (\%) & - & $5(13.9)$ \\
\hline No, $n(\%)$ & - & $26(72.2)$ \\
\hline Ex-smoking, n (\%) & - & $5(13.9)$ \\
\hline Smoking onset age, Yes/No, $n$ (\%) & - & - \\
\hline Smoking duration & - & - \\
\hline $10-20$ years, $n(\%)$ & - & $2(5.6)$ \\
\hline $20-30$ years, $n(\%)$ & - & $5(13.9)$ \\
\hline$>30$ years, $\mathrm{n}(\%)$ & - & $3(8.3)$ \\
\hline Daily cigarette consumption & & - \\
\hline One package, $\mathrm{n}(\%)$ & - & $3(8.3)$ \\
\hline > One package, $n(\%)$ & & $6(16.7)$ \\
\hline Alcohol consumption, Yes/No, n (\%) & - & $6 / 30(16.7 / 83.3)$ \\
\hline \multicolumn{3}{|l|}{ Frequency of alcohol consumption } \\
\hline Daily, n (\%) & - & $4(11.1)$ \\
\hline Social drinker, $\mathrm{n}(\%)$ & - & $2(5.6)$ \\
\hline Family history, Yes/No, n (\%) & - & 29/7 (80.6/19.4) \\
\hline Response to treatment, Yes/No, n (\%) & - & $27 / 9(75.0 / 25.0)$ \\
\hline \multicolumn{3}{|l|}{ Patients status } \\
\hline Alive, $\mathrm{n}(\%)$ & - & $29(80.6)$ \\
\hline Exitus, n (\%) & - & $7(19.4)$ \\
\hline \multicolumn{3}{|l|}{ Disease State } \\
\hline Complete response, $\mathrm{n}(\%)$ & - & $26(72.2)$ \\
\hline Stable disease, $\mathrm{n}(\%)$ & - & $1(2.8)$ \\
\hline Metastatic disease, n (\%) & - & $9(25.0)$ \\
\hline \multicolumn{3}{|l|}{ Disease area } \\
\hline Intra-oral, n (\%) & - & $3(8.3)$ \\
\hline Floor of the mouth, $\mathrm{n}(\%)$ & - & $2(5.5)$ \\
\hline Buccal, n (\%) & - & $1(2.8)$ \\
\hline Roof of the mouth, $\mathrm{n}(\%)$ & - & $2(5.5)$ \\
\hline Tongue, $\mathrm{n}(\%)$ & - & $9(25)$ \\
\hline Lip, n (\%) & - & $16(44.4)$ \\
\hline Oral mucosa, $\mathrm{n}(\%)$ & - & $1(2.8)$ \\
\hline Tonsil, n (\%) & - & $1(2.8)$ \\
\hline Cheek mucosa, n (\%) & - & $1(2.8)$ \\
\hline
\end{tabular}

in patients were as follows: 8 individuals (22.22\%) had 1/1 genotype, 26 (72.22\%) had $1 / 2+2 / 2$ genotype, and $2(5.56 \%)$ had $1 / 3+3 / 3$ genotype. In the control group, the genotypic frequencies of the VNTR IL-1RA polymorphism were as follows: 54 individuals (54\%) had 1/1 genotype, $40(40 \%)$ had $1 / 2+2 / 2$ genotype, and $6(6 \%)$ had $1 / 3+1 / 3$ genotype. The frequencies of IL-1RA $1 / 2+2 / 2$ genotypes were more common in the patients than healthy controls while IL-1RA VNTR $1 / 1$ genotype was higher in the control group than in the patients $\left(p=0.002, X^{2}=12.011\right)$.
The allele frequencies of IL-1RA VNTR showed a significant difference between the patient and the control groups. IL-1RA VNTR allele 1 was higher in the control group than the patient group while IL-1RA VNTR allele 2 was higher in the patient group than the control group ( $p=0.000$, OR: $0.369,95 \% \mathrm{Cl}: 0.204-0.656 ; p=0.000$, OR: $2.609,95 \% \mathrm{Cl}:$ 1.503-4.580, respectively). The subjects carrying allele 2 showed a 2.609fold increased risk of susceptibility to OSCC. 
Table 2. Genotype and allele frequencies of IL-1RA VNTR variant in OSCC patients and controls

\begin{tabular}{|c|c|c|c|c|c|}
\hline \multicolumn{4}{|l|}{ Genotypes } & $\mathrm{X}^{2}$ & $p$ \\
\hline IL-1RA & $1 / 1 \mathrm{n}(\%)$ & $1 / 2+2 / 2$ n (\%) & $1 / 3+3 / 3$ n (\%) & \multirow{3}{*}{12.011} & \multirow{3}{*}{0.002} \\
\hline Patients $(n=36)$ & $8(22.22)$ & $26(72.22)$ & $2(5.56)$ & & \\
\hline Controls $(n=100)$ & $54(54.00)$ & $40(40.00)$ & $6(6.00)$ & & \\
\hline \multicolumn{6}{|l|}{ Alleles } \\
\hline & IL-1RA 1 (+/-) & IL-1RA 2 (+/-) & IL-1RA 3 (+/-) & \multirow{5}{*}{ - } & \\
\hline Patients & $24 / 48(33.33 / 66.67)$ & $44 / 28(61.11 / 38.89)$ & $2 / 70(2.78 / 97.22)$ & & \\
\hline Controls & $113 / 87(56.50 / 43.50)$ & $75 / 125(37.50 / 62.50)$ & $12 / 188(6.00 / 94.00)$ & & \\
\hline OR (CI 95\%) & $0.369(0.204-0.656)$ & $2.609(1.503-4.580)$ & $0.448(0.066-1.833)$ & & \\
\hline$p$ & 0.000 & 0.000 & $>0.05$ & & \\
\hline
\end{tabular}

\begin{tabular}{|c|c|c|c|c|c|}
\hline Gene & osCC patients, $n=36(\%)$ & Controls, $\mathrm{n}=100(\%)$ & $\mathrm{X}^{2}$ & p & OR (CI 95\%) \\
\hline \multicolumn{6}{|c|}{ IL-4 VNTR } \\
\hline \multicolumn{6}{|c|}{ Genotypes } \\
\hline P1/P1 & $1(2.78)$ & $0(0.00)$ & \multirow{6}{*}{6.514} & \multirow{6}{*}{$\begin{array}{l}0.039 \\
0.030\end{array}$} & \multirow{6}{*}{$2.646(1.13-6.10)$} \\
\hline P1/P2 & $10(27.78)$ & $14(14.00)$ & & & \\
\hline $\mathrm{P} 2 / \mathrm{P} 2$ & $25(69.44)$ & $86(86.00)$ & & & \\
\hline \multicolumn{3}{|c|}{ Alleles } & & & \\
\hline P1 & $12(16.67)$ & $14(7.00)$ & & & \\
\hline P2 & 60 (83.33) & 186 (93.00) & & & \\
\hline
\end{tabular}

\section{IL-4 genotyping}

The allelic and genotype frequencies of the IL-4 VNTR polymorphism among the patients with OSCC and the healthy controls are shown in Table 3. The frequencies of P1/P1, P1/P2, and P2/P2 genotypes of IL-4 VNTR polymorphism in the control group were $0 \%, 14 \%$, and $86 \%$, respectively; and $2.78 \%, 27.78 \%$, and $69.44 \%$ in OSCC patients, respectively. There was a significant difference in the distribution of both genotypic and allelic frequencies between OSCC patients and the control group. The IL-4 VNTR $\mathrm{P} 1 / \mathrm{P} 1$ and P1/P2 genotype frequencies were higher in the patient group compared to the control group while the P2/P2 genotype frequency was higher in the controls compared to the patients $\left(p=0.039, X^{2}=6.514\right.$ ) (Table 3). IL-4 VNTR P1 allele was higher in the patients compared to the controls while IL-4 VNTR P2 allele was higher in the control group than the patients ( $p=0.030$; OR: $2.646,95 \% \mathrm{Cl}: 1.13-6.10)$.

\section{Discussion}

In the present study, we scrutinized whether functional VNTR polymorphisms of the IL-1RA and IL-4 were associated with OSCC in a Turkish population. OSCC is an aggressive epithelial cancer. Despite early diagnosis and several treatments, the overall survival rate of patients with OSCC is still low (9). The immune response to inflammation is commonly involved in the cancer pathogenesis. Genetic changes also take place in the inflammatory response that could be linked with the risk of several cancers, including the OSCC. Functional DNA polymorphisms affecting gene expression of inflammatory molecules were reported to predispose the individual to disease and worsen the prognosis. Studies suggest that serum levels of inflammatory cytokines (including TNF- $\alpha$ and TNF- $\beta$ (TNF- $\alpha$ and TNF- $\beta$ ), IL-6, IL-8) and anti-inflammatory cytokines (such as IL-10) are likely to be associated with carcinogenesis via multiple and usually controversial pathways, thus they may have a prognostic importance in OSCC and other cancer types (10-12).

IL-1RA is a crucial immunologic modulator and its expression inhibits pro-inflammatory signals from cellular damages during wide immunologic responses (3). In intron 2 of the $I L-1 R A$ gene, a variant due to the presence of variable numbers of an 86-bp VNTR was described. Although this IL-1RA VNTR-polymorphism is found in intron 2, it is probably responsible for a change in IL-1RA synthesis (13). The number of repeats, present in intron 2 of the IL-1RA gene, may manifest a functional role as it is thought that each repeat has considerable number of binding sites for transcription factors. Thus, a higher amount number of repeats would result in a higher transcriptional activity. IL1RA alleles 1-5 contain 4 repeats, 2 repeats, 5 repeats, 3 repeats, and 6 repeats, respectively. The role of IL-1RA VNTR polymorphism has been investigated for years in the development of inflammatory diseases. Actually, some studies reported different relations of IL-1RA VNTR alleles with the occurrence of some cancers, including gastric (14), 
esophageal (15), bladder (16), breast (17), colorectal (18), lung (19), brain (20), and nasopharyngeal (21). In a meta-analysis evaluating the relationship between IL-1RA VNTR variant and cancer, Zhang et al. (22) suggested that the IL1-RA VNTR variant might play a role in the genetic susceptibility to gastric cancer. Shiiba et al. (23) reported that expression of IL-1RA mRNA was significantly downregulated in OSCCs compared to normal tissues. Also, they demonstrated that IL-1RA expression level was lower in the oral premalignant lesion cases with severe dysplasia compared to those with mild/moderate dysplasia. Gupta et al. (24) reported that the percentage of IL-1RA I/2 individuals was higher in patients with OSCC than controls. Additionally, in carriage rate analysis, they reported that 2 allele of IL-1RA was to be significantly associated with OSCC. In the present study, statistical analysis of the IL-1RA allele and genotype frequencies in the OSCC patient group affirms the significance of the IL-1RA VNTR variant in OSCC in comparison to the control population. Despite the small sample size in our study, we found a significant association with OSCC and IL-1RA VNTR variant. IL-1RA VNTR $1 / 2+2 / 2$ genotypes were more common in patients than healthy controls. The subjects carrying IL-1RA VNTR $1 / 2+2 / 2$ genotypes showed a 12.011-fold increased risk of susceptibility to OSCC. (Table 2). IL-1RA VNTR allele 1, associated with high IL-1RA levels, was lower in patients. Conversely, IL-1RA allele 2, leading to an inadequate synthesis of IL-1RA protein or to an overproduction of IL-1 $\beta$ in response, was higher in the patient group $(p=0.00)$. The subjects carrying allele 2 showed a 2.609 -fold increased risk of susceptibility to OSCC. This condition could explain why carriage of IL-1RA allele 2 could influence an individual's susceptibility to OSCC. Our results were consistent with those reported by Gupta et al. (24).

IL-4 is a fundamental differentiation cytokine that stimulates development of Th2 subset of lymphocytes. This group of lymphocytes activates granulocytes and eosinophils and inhibits angiogenesis, making it crucial in surveillance and clearance of tumor cells (25). IL-4 is a strong modulator of anti-tumor immune responses with both tumor-promoting and tumor-inhibiting features because it acts as both immunosuppressive and anti-angiogenic factor (26). More and more epidemiologic studies have been performed to examine the impact of some IL-4 variants on human cancer risk. The IL-4 VNTR variant could change messenger ribonucleic acid splicing, which leads to different splice variants (27). There is strong evidence that the IL-4 intron 3 VNTR polymorphism might affect the synthesis of IL-4, with the P1 (two 70-bp repeats) allele enhancing IL-4 expression compared to P2 (three 70-bp repeats) allele (8). In a study, Duan et al. (25) evaluated eight eligible case-control studies including 1583 cases and 1638 controls with respect to the relationship of IL-4 VNTR variant and cancer. They indicated that the IL-4 VNTR RP2 allele was related to a reduced cancer risk compared to the RP1 allele. In subgroup analyses, they stratified by ethnicity and they found that there was evidence in the Asian population for an association between this variant and cancer risk. In a meta-analysis performed on 1896 patients and 2526 controls for IL-4 VNTR variant, Jia et al. (28) reported that IL-4 VNTR variant was associated with a higher risk of bladder cancer risk. Also, they showed that IL-4-33CT (rs2070874) variant was correlated with leukemia and oral carcinoma. Yang et al. (29) demonstrated that IL-4 VNTR P1/P1 geno type was associated with an increased risk of OSCC, particularly early-stage OSCC.
In the present study, IL-4 VNTR P1/P1 genotype and P1 allele, a higher IL-4 production allele and genotype, were more common in the patient group ( $p=0.039, p=0.030$, respectively). The subjects carrying IL-4 VNTR P1/P1 genotype showed a 6.514 -fold increased risk of susceptibility to OSCC (Table 3). Our findings are compatible with the potentially growthpromoting effect of IL-4 on OSCC.

\section{Conclusion}

The results of this study revealed an association of both IL-1RA and IL-4 VNTR polymorphisms with the occurrence of OSCC. To the best of our knowledge, this is the first research study to evaluate an association between IL-1RA and IL-4 VNTR polymorphisms and the risk of OSCC in a Turkish population. In conclusion, within the limitations of ethnicity, sample size and sample selection, the IL-1RA and IL-4 VNTR polymorphisms seem to be associated with developing OSCC.

Ethics Committee Approval: The study was carried out in compliance with the Declaration of Helsinki and was approved by the Hitit University Faculty of Medicine Regional Ethical Committee (decision no: 2017/200)

Informed Consent: Informed consent was obtained from all participants before they were enrolled in this study.

Peer-review: Externally peer-reviewed.

Author Contributions: Concept - S.Y., A.T.; Design - A.F.N., S.Y., T.Ö.; Supervision - A.F.N., S.Y., A.T.; Resources - Ö.G. S.Y., A.T.; Data Collection and/or Processing - Ö.G., A.T., T.Ö.; Analysis and/or Interpretation - S.Y., A.T., T.Ö.; Literature Search - A.F.N., A.T.; Writing Manuscript - Ö.G., A.F.N., S.Y.; Critical Review - A.F.N., S.Y., A.T.

Conflict of Interest: No conflict of interest was declared by the authors.

Financial Disclosure: The authors declared that this study received no financial support.

\section{References}

1. Xie S, Luo C, Shan X, Zhao S, He J, Cai Z. CYP1A Mspl polymorphism and the risk of oral squamous cell carcinoma: Evidence from a meta-analysis. Mol Clin Oncol 2016; 4: 660-6.

2. Gaur P, Mittal M, Mohanti B, Das S. Functional variants of IL-4 and IL-6 genes and risk of tobacco-related oral carcinoma in high-risk Asian Indians. Oral Dis 2011; 17: 720-6

3. Arend WP. Interleukin 1 receptor antagonist. A new member of the interleukin 1 family. J Clin Invest 1991; 88: 1445-51.

4. Tarlow JK, Blakemore AI, Lennard A, Solari R, Hughes HN, Steinkasserer A, et al. Polymorphism in human IL-1 receptor antagonist gene intron 2 is caused by variable numbers of an 86-bp tandem repeat. Hum Genet 1993; 91: 403-4.

5. Qian N, Chen X, Han S, Qiang F, Jin G, Zhou X, et al. Circulating IL- $1 \beta$ levels, polymorphisms of IL-1B, and risk of cervical cancer in Chinese women. J Cancer Res Clin Oncol 2010; 136: 709-16.

6. Jha AN, Singh VK, Kumari N, Singh A, Antony J, van Tong H, et al. IL-4 haplotype590T, -34T and intron-3 VNTR R2 is associated with reduced malaria risk among ancestral indian tribal populations. PloS One 2012; 7: e48136.

7. Pérez-Suárez TG, Gutiérrez-Robledo LM, Ávila-Funes JA, Acosta JL, EscamillaTilch M, Padilla-Gutiérrez JR, et al. VNTR polymorphisms of the IL-4 and IL-1RN genes and their relationship with frailty syndrome in Mexican communitydwelling elderly. Aging Clin Exp Res 2016; 28: 823-32. 
8. Mout R, Willemze R, Landegent JE. Repeat polymorphisms in the interleukin-4 gene (IL-4). Nucleic Acids Res 1991; 19: 3763.

9. Blatt S, Krüger M, Ziebart T, Sagheb K, Schiegnitz E, Goetze E, et al. Biomarkers in diagnosis and therapy of oral squamous cell carcinoma: A review of the literature. J Craniomaxillofac Surg 2017; 45: 722-30.

10. Jablonska E, Piotrowski L, Grabowska Z. Serum Levels of IL-1b, IL-6, TNFa, a, sTNF-RI and CRP in patients with oral cavity cancer. Pathol Oncol Res 1997; 3: $126-9$.

11. Fujieda S, Sunaga H, Tsuzuki H, Fan GK, Saito H. IL-10 expression is associated with the expression of platelet-derived endothelial cell growth factor and prognosis in oral and oropharyngeal carcinoma. Cancer Lett 1999; 136: 1-9.

12. St John MA, Li Y, Zhou X, Denny P, Ho CM, Montemagno C, et al. Interleukin-6 and interleukin-8 as potential biomarkers for oral cavity and oropharyngeal squamous cell carcinoma. Arch Otolaryngol Head Neck Surg 2004; 130: 92935

13. Vijgen L, Van Gysel M, Rector A, Thoelen I, Esters N, Ceelen T, et al. Interleukin-1 receptor antagonist VNTR-polymorphism in inflammatory bowel disease. Genes Immun 2002; 3: 400-6.

14. Persson C, Canedo P, Machado JC, El-Omar E.M, Forman D. Polymorphisms in inflammatory response genes and their association with gastric cancer: a HuGE systematic review and meta-analyses. Am J Epidemiol 2011; 173: 25970 .

15. Upadhyay R, Jain M, Kumar S, Ghoshal UC, Mittal B. Potential influence of interleukin-1 haplotype IL-1 beta-511 ${ }^{*} \mathrm{~T}-\mathrm{IL}-1 \mathrm{RN} * 1$ in conferring low risk to middle third location of esophageal cancer: a case-control study. Hum Immunol 2008; 69: 179-86.

16. Vishnoi M, Pandey SN, Choudhuri G, Mittal B. IL-1 gene polymorphisms and genetic susceptibility of gallbladder cancer in a north Indian population. Cancer Genet Cytogenet 2008; 186: 63-8.

17. Lee KM, Park SK, Hamajima N, Tajima K, Choi JY, Noh DY, et al. Genetic polymorphisms of interleukin-1 beta (IL-1B) and IL-1 receptor antagonist (IL$1 \mathrm{RN}$ ) and breast cancer risk in Korean women. Breast Cancer Res Treat 2006; 96: 197-202.

18. Viet HT, Wågsäter D, Hugander A, Dimberg J. Interleukin-1 receptor antagonist gene polymorphism in human colorectal cancer. Oncol Rep 2005; 14: 915-8.

19. Lind H, Zienolddiny S, Ryberg D, Skaug V, Phillips DH, Haugen A. Interleukin 1 receptor antagonist gene polymorphism and risk of lung cancer: a possible interaction with polymorphisms in the interleukin 1 beta gene. Lung Cancer 2005; 50: 285-90.

20. Badr El-Din NK, Settin A, Ali N, Abdel-Hady el-SK, Salem FK. Cytokine gene polymorphisms in Egyptian cases with brain tumors. J Egypt Natl Cancer Inst 2009; 21: 101-6

21. Yang ZH, Dai Q, Zhong L, Zhang X, Guo QX, Li SN. Association of IL-1 polymorphisms and IL-1 serum levels with susceptibility to nasopharyngeal carcinoma. Mol Carcinog 2011; 50: 208-14.

22. Zhang Y, Liu C, Peng H, Zhang J, Feng Q. IL1 receptor antagonist gene IL1RN variable number of tandem repeats polymorphism and cancer risk: a literature review and meta-analysis. PLoS One 2012; 7: e46017.

23. Shiiba M, Saito K, Yamagami H, Nakashima D, Higo M, Kasamatsu A, et al Interleukin-1 receptor antagonist (IL1RN) is associated with suppression of early carcinogenic events in human oral malignancies. Int J Oncol 2015; 46: 1978-84.

24. Gupta MK, Sagar N, Pant R, Banerjee M. Cytokıne gene polymorphısms and their association with oral squamous cell carcinoma (OSCC): A North Indian Study. EJPMR 2016; 550-8.

25. Duan Y, Pan C, Shi J, Chen H, Zhang S. Association between interleukin-4 gene intron 3 VNTR polymorphism and cancer risk. Cancer Cell Int 2014; 14: 131.

26. Aggarwal BB, Vijayalekshmi RV, Sung B. Targeting inflammatory pathways for prevention and therapy of cancer: short-term friend, long-term foe. Clin Cancer Res 2009; 15: 425-30.

27. Inanir A, Tural S, Yigit S, Kalkan G, Pancar GS, Demir HD, et al. Association of IL-4 gene VNTR variant with deep venous thrombosis in Behçet's disease and its effect on ocular involvement. Mol Vis 2013; 19: 675-83.

28. Jia Y, Xie X, Shi X, Li S. Associations of common IL-4 gene polymorphisms with cancer risk: A meta-analysis. Mol Med Rep 2017; 16: 1927-45.

29. Yang CM, Chen HC, Hou YY, Lee MC, Liou HH, Huang SJ, et al. A high IL-4 production diplotype is associated with an increased risk but better prognosis of oral and pharyngeal carcinomas. Arch Oral Biol 2014; 59: 35-46. 